\title{
AUTHOR INDEX VOLUME 141
}

ACCARDO, A., see BRUN, F. $\quad$ 233-243

AMETOVA, E., see SHKARIN, A. $\quad$ 259-274

AMETOVA, E., see SHKARIN, R. $\quad$ 245-258

ARUN KUMAR AND M. BANERJEE, Algebras of Definable and Rough Sets in Quasi Order-based Approximation Spaces $\quad 37-55$

BALÁZS, P., see HANTOS, N.

BALÁZS, P., Z. OZSVÁR, T.S. TASI, L.G. NYÚL, A Measure of Directional Convexity Inspired by Binary Tomography

BANERJEE, M., see ARUN KUMAR

BASU, T. AND C.A. MURTHY, A Similarity Based Supervised Decision Rule for Qualitative Improvement of Text Categorization

BATTAGLINO, D., see FROSINI, A.

BORTOLUSSI, L., L.P. DINU, L. FRANZOI AND A. SGARRO, Coding Theory: A General Framework and Two Inverse Problems

BRUN, F., S. PACILÈ, A. ACCARDO, G. KOUROUSIAS, D. DREOSSI, L. MANCINI, G. TROMBA AND R. PUGLIESE, Enhanced and Flexible Software Tools for X-ray Computed Tomography at the Italian Synchrotron Radiation Facility Elettra

CATTANEO, G., G. CHIASELOTTI, T. GENTILE AND P.A. OLIVERIO, The Lattice Structure of Equally Extended Signed Partitions

CHIASELOTTI, G., see CATTANEO, G.

CHILINGARYAN, S., see SHKARIN, A.

CHILINGARYAN, S., see SHKARIN, R.

$245-258$

CHRZA, STOWSKI-WACHTEL, P., see SROKA, J.

367-398

DICKY, A. AND D. JANIN, Two-way Automata and Regular Languages of Overlapping Tiles

DREOSSI, D., see BRUN, F.

DRITSCHLER, T., see SHKARIN, A.

259-274

DRITSCHLER, T., see SHKARIN, R.

DURNOGA, K. AND B. ŹRAŁEK, On Computing Discrete Logarithms in Bulk and Randomness Extractors

FIORINI, R.A., Computerized Tomography Noise Reduction by CICT Optimized Exponential Cyclic Sequences (OECS) Co-domain

FRANZOI, L., see BORTOLUSSI, L.

FROSINI, A., D. BATTAGLINO, S. RINALDI AND S. SOCCI, The Identity

Transform of a Permutation and its Applications

GAO, Y., see SHAO, Z.

GENTILE, T., see CATTANEO, G.

HANTOS, N. AND P. BALÁZS, Eliminating Switching Components in Binary

Matrices by $0-1$ Flips and Column Permutations

$115-134$

297-310

$191-205$

95-114

$1-36$

HIDDERS, J., see SROKA, J.

135- 150

367-398

311-343

JANIN, D., see DICKY, A.

259-274

KOPMANN, A., see SHKARIN, A.

245-258

KOPMANN, A., see SHKARIN, R.

233-243

KUZIAK, D., I.G. YERO AND J.A. RODRÍGUEZ-VELÁZQUEZ, On the Strong Metric Dimension of Cartesian Sum Graphs 
MANCINI, L., see BRUN, F.

MIRONE, A., see SHKARIN, R.

MURTHY, C.A., see BASU, T.

NAGY, A., Experimental Study on Multivalued Phantoms Using Different Filters in the DART Algorithm

PACILÈ, S., see BRUN, F.

PENG, X. AND Y. YANG, Interval-valued Hesitant Fuzzy Soft Sets and their Application in Decision Making

SHAO, Z. AND Y. GAO, Certificate-based Fair Exchange Protocol of Schnorr Signatures in Chosen-key Model

SHKARIN, A., S. CHILINGARYAN, T. DRITSCHLER, A. KOPMANN, M. VOGELGESANG, S. TSAPKO, E. AMETOVA AND R. SHKARIN, An Open Source GPU Accelerated Framework for Flexible Algebraic Reconstruction at Synchrotron Light Sources

SHKARIN, A., S. CHILINGARYAN, T. DRITSCHLER, A. KOPMANN, M. VOGELGESANG, S. TSAPKO, E. AMETOVA AND R. SHKARIN, An Open Source GPU Accelerated Framework for Flexible Algebraic Reconstruction at Synchrotron Light Sources

SHKARIN, R., S. CHILINGARYAN, T. DRITSCHLER, A. KOPMANN, A. SHKARIN, M. VOGELGESANG, E. AMETOVA, A. MIRONE AND

S. TSAPKO, GPU-optimized Direct Fourier Method for On-line Tomography 